\title{
Battered by Men and Bruised by Law: Women in Quagmire
}

\author{
*Parul Parihar, \\ PhD Scholar, Deptt of Sociology, Bharatividyapeeth University, Pune, \\ M.A, M/Phil Sociology, J.N.U New Delhi.
}

\begin{abstract}
"Violence against women is perhaps the most shameful human rights violation. And it is perhaps the most pervasive. It knows no boundaries of geography, culture or wealth. As long as it continues, we can't claim to be making real progress towards equality, development and peace", Kofi Annan, Secretary - General of the United States, 2006.
\end{abstract}

Violence against Women has assumed enormous significance because of being a major issue of concern and debate at the international level since the late sixties. Subsequent to the Battered Women's Movement of the eighties, violence against women gained greater momentum. The World's conference on Human Rights in Vienna, 1993 and the 1995 Beijing Conference added impetus to the movement where an urgent need was highlighted so as to focus on systematic research and multiple dimensions of violence against women across the countries and regions. This, it was felt would provide a firm and reliable base for policy intervention. The Violence against Women in India is rapt with torture of brides, dowry deaths, cruelty perpetrated on married women through conduct, be that physical, psychological or emotional.

Violence against Women is a universally pervasive problem. Besides the physical, psychological and emotional damage to the victims, children become the direct target of the adverse impact it causes on their personality development and health. The economic costs to nation caused by loss of women's labour on account of physical injuries, depression and homicide linked to violence against women are compelling considerations requiring immediate social redress. A woman suffers not only because of violence at home but for aftermath of the same in the police stations, in the hospitals, in the courts, among the family members, friends, neighbours, in matrimonial sphere and so on. Victimized women are subjected to social stigma, fear of reprisal and public criticism, ostracism and emotional trauma. Above all the inability of the states to ensure violence free existence for one half of the humanity is a rather sad commentary on the status of human rights of women. It needs critical policy intervention as being recognized by international agencies concerned and involved with women's development.

"According to the official figures recorded, daily one woman is raped and 15 die unnatural deaths. Majority of these unnatural deaths occur inside their homes," said Poonam Kathuria of an NGO Swati (Domestic Violence: A violation of Human Rights of Women, Dr.Vibhuti Patel, Director, and P.G.S.P). Manjula Pradeep of Navsarjan Trust said that women from the minority and Dalit community suffer dual exploitation on the basis of caste and gender. She said that there is an alarming rise in the number of rapes on minor girls where conviction is almost nil (TNN, Dec 9; 2009, 1:55am IST 'Women Violation of Human Rights').

Today violence against women is no longer invisible. Both the NGOs and the government no longer harbor myths of safe and secure homes. Sustained campaigns against rape, bride burning, sexual harassment, intra familial violence, degrading media portrayals and Sati have all contributed to making violence against women, a political issue.

The Declaration on Elimination of Violence against Women, 1993 affirms that States must "exercise due diligence to prevent, investigate and in accordance with national legislation punish the acts of violence against women, whether such acts are perpetrated by the State or Private Persons.

Notwithstanding many legal reforms, societal responses to domestic violence still largely exclude legal intervention. Women's access to these laws is very rare as male batterers are not asserted, prosecuted, or sentenced as severely as other violent offenders which are confirmed by studies (Law Resource India; Protecting Women from Domestic Violence posted in Crime against Women, Criminal Justice System, Domestic Violence, Fundamental Rights, Gender and Women Empowerment; NNLRJ INDIA, March 19; 2011).

Violence in the private sphere of the family and victimization of women in the intimate relationships has acquired legitimacy and urgent attention in the legal discourse. This recognition identifies violence in the private sphere not merely as a crime into the systematic process of structural subordination of women in a gendered social order. Where violence reconfirms and reproduces those gender hierarchies through fear, which produce this violence in the first instance. It was argued that "personal is political" and that the inner world of family should be open to public scrutiny so that the inequalities and power relations within the family could be made visible (Vineet Kapoor; The Tribune). 
Within Sociology, the study of women has been subsumed under the general headings of family or sex and gender studies, while the substantive work in the field has focused on men and men's lives (Smith, 1974; Nebraska Sociological Feminist Collective, 1983). "In sociology, woman as an object of study is largely ignored. Only in the field of marriage and the family is she seen to exist. Her place in sociology is, in other words, the traditional one assigned to her by the larger society: women's place is in the home" (Ehrlich, 1971:421).

Violence against Women is a phenomenon that cuts across boundaries of culture, class, education, ethnicity and age. Female Feticides, domestic violence, dowry deaths or harassment, mental and physical torture, sexual trafficking and public humiliation are some common forms of gender based violence against women. Most of this violence is domestic, occurring within home, perpetrated by those to whom the woman is closest. The legal system tends to re-intensify the patriarchal social structure and there is a wide gap between the laws as it exists on paper and the manner in which it is implemented; the law sees women through gender lens as wives, mothers, and daughters-in-laws and not in their identity as citizen of the land in search of justice.

Domestic Violence became an issue of concern in the 1980's with the incidences of 'dowry deaths' rising steadily in India. This led to grassroots activism. They wanted to secure human rights for women without appearing to threaten family values. The cruelty and homicide of women for economic reasons was unique to India and had caught the attention of the national and international media. Hence, the activists focused their attention on the problem of dowry and dowry death. The women's organizations across the country pressurized the Criminal Law Amendment Committee (1982) and urged the government to bring out legislation to protect women against domestic violence and dowry, so that the victim gets justice while she is still alive. As a result of the intense campaigning and lobbying, significant amendments were made in the Indian Evidence Act and the Dowry Prohibition Act, with the intention of protecting women from marital violence, abuse and dowry demands. The most notable sections are 304 B, 406 and 498A of the Indian Penal Code, and Section 113A of the Indian Evidence Act.

\section{Assumptions and Propositions of Major Sociological Contributors}

An overview of historical sociological theory and women's place in it is explained by outlining some of the major assumptions put forth by the founding fathers of sociology and other renowned contributors.

The first of these are the positivist, functionalist theorists, who assert the "natural" order of male dominance as a contrast to arguments for women's "rights". The second are the conflict theorists, who describe systems of oppression that systematically restrict women. Finally, we assess the contribution of alternative perspectives, including activist models such as social work and interactionist perspectives.

From the earliest analyses of society, the family was the most fundamental unit of society, parallel to the biological concept of the cell. Women were discussed only in their relation to this unit. The Italian philosopher, Giambattista Vico wrote in his book The New Science that: Men mean to gratify their bestial lust and abandon their offspring, and they inaugurate the chastity of marriage from which the families arise. The fathers mean to exercise without restraint their paternal power over their clients, and they subject them to the civil powers from which the cities arise (1948 \{original 1744\}: 425).

According to Auguste Comte, Women are "Constitutionally" inferior to men since their maturation ends in childhood. Therefore, he believed that women become subordinated to men when they marry. Divorce was denied to women since they were simply the pampered slaves of men. To counter the nineteenth century argument that women were more stupid than men because they had smaller brains, she is a man, a father, and infected too" (as quoted in Sydie, 1987:207). This distorted "genderization of science" means that the discipline is dominated by male thought and male activity.

Herbert Spencer's organic model as applied to women is the assumption of linearity. Given the focus on social evolution within the functionalist framework, these theorists assume that what exists now is an improvement on what came before. As societies evolve in a linear fashion, (from simple to complex), it is dysfunctional to interfere with this evolutionary process through social action, revolution, or other activities aimed at changing the social order or the status quo. These social actions might lead to social disequilibrium.

Citing Durkheim, his discussions of women in two narrow contexts are significant: The first was the positivist nexus of marriage and family: women fulfilled traditional roles he perceived as functional to the family. The second was the negative nexus of suicide/ divorce and sexuality in which women's sexuality played a role in suicide and divorce (Lehmann, 1990). Within the family, women relinquish authority to men, or men assume authority because the family is in need of a "chief" (Lehmann, 1990:33). This authority includes control over the economic resources and a sexual division of labour within the family which relegates women to inferior, private, and asocial roles that are based on the differences in inherent abilities and social morality. It is this asocial nature of women that also shapes Durkheim's proposition about suicide and divorce. The lower suicide rates of women are explained by Durkheim as evidence that they are less involved in public arenas of activity (as are the elderly and children) (Lehmann, 1990:12). 
In Communist Manifesto (1970), Marx and Engels wrote about women as instruments of productions. Fredrick Engels, in "The Origin of the Family, Private Property and the State", did write specifically about the oppression of women within the family: In the great majority of cases today, at least in the possessing classes, the husband is obliged to earn a living and support his family, and that in itself gives him a position of supremacy, without any need for special legal titles and privileges. Within the family he is bourgeois and the wife represents the proletariat.

Equally important is Max Weber's writings focusing on the interrelationships among class, status, and power. To Weber, Class is the economic basis of inequality, loosely organized around classes of "Haves" and "Have -not's". To this, he adds Social Status - the notion of honour or prestige that can be bestowed by family background, occupational activities, or consumption patterns. His third dimension, power, refers explicitly to political rights and resources. These dimensions overlap significantly in advanced industrial societies, but Weber was interested in the variations among them. For example, a woman may be held in low status by virtue of her gender and have few economic resources or political rights. However, her occupation as nurse may bestow her with a certain amount of status honour in communities that value the nurturing, care taking roles of women. For the analysis of women in society, this was an important development because status or one's position in a social order is related to power. Women's status in society could now be analyzed in terms of their disadvantages in both economic and social power, and the construction of social prestige as it related to gender and occupational roles. These multiple dimensions are not prioritized by Weber, although he notes the importance of economic resources as a means of assessing the other two dimensions. Weber also purported a Value -Free Sociology or Sociology with a focus on objectivity. In contemporary Sociology, this emphasis on objectivity enabled the discipline to adopt scientific models that establish positivist methods and scientific observations. Historically, both the status of observer and the definition of scientific norms have been monopolized by men, which can trivialize or make invisible women's experiences. This focus on objectivity and the certification of observers excludes women's subjective experiences, making them either "invisible" or "nonscientific" (NebrasakaSociological Feminist Collective, 1983).

\section{Jane Adams ---- Social Work Model}

James, a cultural feminist who asserted that female values were superior to male values and that society built on feminine values would be more "Productive, peaceful and just"(Deegan,1988). This belief was based on the premise that women were biologically superior because of their maternal instinct. These ideas were a strong impetus for Adam's pacifism which eventually resulted in her receiving the Nobel Peace Prize in 1931.

\section{George Herbert Mead ------Symbolic Interactionism}

Symbolic Interactionism is a perspective focusing on the interpersonal and the relationship between the personal and the structural often referred to as microsociology. The importance of symbolic interactionism is in the recognition of the significance of the interplay between social structure (macrosociology) --- defined as process and habits or patterns of interacting and personality (microsociology) (Mead, 1934). This theme emphasizes human society as being in process, rather than as static. Symbolic interactionists also recognize that individual acts and interpretations take place within the context of groups and institutions and those individuals have varying resources within those settings to create change (Manis and Meltzer, 1978). This interpretative approach focusses on the symbolic meaning attached to social life and has profound implications for understanding women in society. ( cited in "A Sociology of Women; Jane C.Ollenburger and Helen A Moore, Pp-6 -13, Prentice Hall, Englewood Cliffs, New Jersey 07632, 1992)"

\section{Women Empowerment and Technological Advancement \\ $>$ United Nation's Definition of Women Empowerment:}

1. Women's sense of self worth

2. Their right to have and to determine choices.

3. Their right to have access to opportunities and resources.

4. Their right to have power to control their own lives, both within and outside the home.

5. Their ability to influence the direction of social change to create a more just, social and economic order, nationally and internationally.

The promotion of Women's empowerment as a development goal is based on a dual argument; that social justice is an important aspect of human welfare and is intrinsically worth pursuing and that women's empowerment is a means to other ends.

Women's empowerment includes cognitive and psychological elements: it involves women's understanding of their conditions of subordination and the causes of such conditions at both micro and macro levels of society. It involves understanding the self and the need to make choices that may go against cultural and social expectations. 
- Empowerment means control over material assets, material resources and ideology.

- It involves power to, power with and power within.

Some define empowerment as a process of awareness and conscientisation, of capacity building leading to greater participation, effective decision making power and control leading to transformative action.

The Cairo Conference in 1994 organized by UN on Population and Development called attention to Women's empowerment as a central focus and UNDP developed the Gender Empowerment Measure which focusses on the three variable that reflect women's participation in society - political or decision making, education and health.

1995 UNDP Report was devoted to women's empowerment and it declared that if human development is not engendered then it is endangered. Equality, Sustainability and Empowerment were emphasized and the stress was, that women's emancipation does not depend on national income but is an engaged political process.

- Women Empowerment must then be derived from something concrete - Knowledge or education. With knowledge, we can critically discern the means of acquiring a healthy sense of identity and power and we can empower ourselves based on what our concrete knowledge tells us is provident and judicious rather than simply not (cited at www.forbes.com/ empowering women for Social and Economic Advancement; Aishwani Khurana, representing India at 2013 Girls 20 Summit/ Qualcomm's Technology, Peggy Johnson, July $10^{\text {th }}$ 2013).

Both Innovation and Gender Equality underpin all of the Millennium Development Goals (MDG's) and both require thinking and acting beyond existing parameters. Both endeavour require transforming the parameters and dimensions.

- At the most basic level, Innovations can benefit simply by improving their well-being in terms of health, nutrition, income, even life span. Beyond vital improvements in well-being, innovations can lead to women's empowerment, securing freedom and resources for women to make decisions, build confidence and act in their own interests. equality.

How Innovations have improved Women's well-being, empowered women and advanced gender

Examining eight catalytic innovations in three domains that intersect areas with the greatest need and most creative entry points for realizing women's empowerment:

1Technological Use

2) Social Norm Change

3) Economic Resilience

$>$ Technological Change:

-The Oral Contraceptive Pill in the US

- Grameen Village Phones in Bangladesh

$>$ Social Norm Change:

-Anti - foot binding campaign in China

-Legislative gender quotas in Argentina

-Campaign to end Female Genital Cutting in Senegal.

$>$ Economic Change / Resilience

-Labour - intensive, export led economic policy in Taiwan

-Microfinance - plus in India

-Land titling in Peru.

Women's movements provided critical support, initially influencing the agenda, and later shaping the direction of innovation process. Definition of Innovation aligns largely with the emerging concept of "Social Innovation", emphasizing not only progress and social change, but also social justice as an important element.

Phills, Deiglmeier and Miller (2008) define social innovation as, "a novel solution to a social problem that is more effective, efficient and sustainable or just than existing solutions and for which the value accrues primarily to society as a whole rather than private individuals". This definition of social innovation balances the need for value accruing directly to women for their greater well-being and empowerment, with an understanding that smart investments in women as development actors also can support the flow of benefits to households communities and wider development process. At the same time, Women Empowerment is defined as "Women's ability to make strategic life choices where that ability had been previously denied to them" (Kabeer 1999).

The 2013 Girls 20 Summit brought together one girl, aged 18-20, from each G-20 country to look at the G-20 Leaders agenda through the lens of the economic empowerment of girls and women.

One of the most important things in the world that "needs to be fixed" is the status of women in economic and social arenas. Merely fighting for women rights is not the solution because the fundamental problem is that of disrespect for women. Sometimes, a woman herself doesn't know her own rights and therefore gives into cultural norms that manipulate gender differences into gender hierarchies. There is a huge 
lag between knowing and doing. That is why it is not surprising to hear the paradoxical cases of well educated women being subjected to domestic violence and sexual harassment.

The World doesn't need better governments to help create this change, but what Aung San Suu Kyi calls, "a revolution of the spirit" to empower women. When it is fixed, success will look like in the form of lesser number of rape cases, molestation cases, sexual harassment and domestic violence. After all, these social problems are not problems in themselves but symptoms of a deep rooted issue; the issue of disgracing and debasing the human life.

The 'revolution of spirit' refers to the ideology that we ourselves are capable of creating the biggest impact and achieving the highest good' (Innovation for Women's Empowerment and Gender Equality, Anju Malhotra, Jeunifer Schulte, Payal Patel,, Patti Petesch; ICRW, 2009) 